\title{
Surface Texturing Behavior of Nano-copper Particles under Various Copper Salts System during Copper-assisted Chemical Etching
}

\section{Shihao Hong}

Kunming University of Science and Technology

Liang Ma

Kunming University of Science and Technology

\section{Xiuhua Chen}

Yunnan University

Shaoyuan Li ( $D$ lsy415808550@163.com )

KUST https://orcid.org/0000-0002-8124-8408

\section{Wenhui Ma}

Kunming University of Science and Technology

\section{Yuanchih Chang}

University of New South Wales

\section{Research Article}

Keywords: Cu-assisted chemical etching, etching behavior, inverted pyramid structure, copper deposition, anions ions effect

Posted Date: July 13th, 2021

DOl: https://doi.org/10.21203/rs.3.rs-697733/v1

License: (9) This work is licensed under a Creative Commons Attribution 4.0 International License. Read Full License 


\title{
Surface Texturing Behavior of Nano-copper Particles under Various Copper Salts System during Copper-assisted Chemical Etching
}

\author{
Shihao Hong ${ }^{\mathrm{a}}$, Liang Ma $\mathrm{Ma}^{\mathrm{a}}$ Xiuhua Chen ${ }^{\mathrm{b}}$, Shaoyuan $\mathrm{Li}^{\mathrm{a} \mathrm{c}^{*}}$, Wenhui Ma ${ }^{\mathrm{a}^{*}}$, Yuanchih Chang ${ }^{\mathrm{c}}$ \\ a Faculty of Metallurgical and Energy Engineering/State Key Laboratory of Complex Nonferrous Metal \\ Resources Clean Utilization, Kunming University of Science and Technology, Kunming 650093, China. \\ b School of Materials and Energy, Yunnan University, Kunming 650091, China \\ c School of Photovoltaic and Renewable Energy Engineering, University of New South Wales. Sydney
} 2052. Australia

Corresponding Author: Shaoyuan Li ( 1sy415808550@163.com), Wenhui Ma(mwhsilicon@126.com)

\begin{abstract}
In this work, the effects of different copper salts on the etching behavior of n-type monocrystalline silicon wafers were detailedly studied by $\mathrm{Cu}$-assisted chemical etching method. Firstly, the inverted pyramid, inverted pyramid-like and oval pit texturing structures were obtained by $\mathrm{HF} / \mathrm{H}_{2} \mathrm{O}_{2} / \mathrm{Cu}\left(\mathrm{NO}_{3}\right)_{2}, \mathrm{HF} / \mathrm{H}_{2} \mathrm{O}_{2} / \mathrm{CuSO}_{4}$ and $\mathrm{HF} / \mathrm{H}_{2} \mathrm{O}_{2} / \mathrm{CuCl}_{2}$ etching systems. Then, the evolution of copper particles deposition behavior was studied to reveal the influencing mechanism of different anion species, the textured wafer surfaces were characterized by scanning electron microscopy (SEM) and ultraviolet-visible (UV) spectrophotometer, the etching rate, silicon wafer thinning and the deposition amount of copper particle was systematically analyzed. We conclude that the binding force between anion and cation, the oxidation of anions and the formation of complex groups $\left[\mathrm{CuCl}_{2}\right]^{-}$lead to great difference in the deposition behavior of copper, resulting in different etching morphology and etching rate. The moderate size copper particles deposited from $\mathrm{HF} / \mathrm{H}_{2} \mathrm{O}_{2} / \mathrm{Cu}\left(\mathrm{NO}_{3}\right)_{2}$ system make that the etching process is mild and the anisotropic etching ability can fully demonstrated, and the regular inverted pyramid structures can be formed under low thinning of silicon wafers. This work will provide guidance for controllable preparation of inverted pyramid structure and future application in high efficiency solar cells.
\end{abstract}

Key words: Cu-assisted chemical etching; etching behavior; inverted pyramid structure; copper deposition; anions ions effect 


\section{Introduction}

Solar energy has become one of the most promising renewable energy sources to replace traditional energy sources because of its clean and pollution-free reserves [1,2], and the installed capacity of photovoltaics has increased dramatically in recent years[3]. The solar cells, which can directly convert sunlight into electrical energy, are undoubtedly the core device of photovoltaic power generation, where the single crystal silicon (sc-Si) solar cell occupied more and more market share due to the continuous technological progress and cost reduction $[4,5]$. Moreover, the $\mathrm{n}$ type silicon show huge potential in developing low-cost and high-efficiency solar cells in the future due to its natural advantages of low light attenuation, high minority carrier lifetime [6,7]. Surface texture is an important optical management strategy for high-efficient silicon solar cell devices[8]. During sc-Si solar cell processing, $\mathrm{KOH}$ anisotropic etching is utilized to texture silicon wafer, and the upright pyramid light trapping structure can be formed, which reduces the reflectivity of silicon wafer to about $15 \%$ [9], however, the upright pyramid is not the most effective anti-reflection structure and it is not an optimal choice in prospective HIT high efficiency cell technology which needs a efficient interfaces passivation.

Metal assisted chemical etching is an effective wet texturing method which could reduce the surface reflectivity by forming highly light-trapping nanostructures[10-12]. In previous work, we have prepared vertical, inclined and zigzag nanowire structures on multi-crystalline silicon (mc-Si) substrates by Ag-assisted chemical etching [13-15]. Besides silver, the copper also show catalytic activity, and inverted pyramids (IPs) structure with ultra-low reflectivity can be obtained by anisotropic etching of copper [16-20]. The IPs structure owns superior light-trapping performance and attracted global attention since 2001, when the research team of the University of New South Wales applied IPs structure to Passivated Emitter and Rear Locally-diffused (PERL) solar cell, which created a efficiency record of $24.7 \%$ [21]. However, this structure has not been quickly applied to photovoltaic devices on a large scale, because it needs lithography and laser processes, which were complicated and expensive. Until 2015, Wang Yan et al obtained IPs structure with low reflectivity on the silicon surface by copper-assisted chemical etching using $\mathrm{HF} / \mathrm{H}_{2} \mathrm{O}_{2} / \mathrm{Cu}\left(\mathrm{NO}_{3}\right)_{2}$ solution, which brought hope for the low-cost preparation of the IPs structure [22]. We also 
fabricated IPs structure with low reflectivity on mc-Si surface [23], moreover, we found that the etched morphologies in different copper salt etchants are quite different[24]. Studying the influence mechanism of anions in different copper salt etching systems will help us further understand the chemical etching mechanism of copper nanoparticle and the formation process of the inverted pyramid.

In this paper, we applied $\mathrm{Cu}$-assisted chemical etching $(\mathrm{Cu}-\mathrm{ACE})$ on n-type monocrystalline silicon wafers, and the different copper salt etchant system of $\mathrm{HF} / \mathrm{H}_{2} \mathrm{O}_{2} / \mathrm{Cu}\left(\mathrm{NO}_{3}\right)_{2}, \mathrm{HF} / \mathrm{H}_{2} \mathrm{O}_{2} / \mathrm{CuSO}_{4}$ and $\mathrm{HF} / \mathrm{H}_{2} \mathrm{O}_{2} / \mathrm{CuCl}_{2}$ ) was selected to explore the influence of anions species on the deposition behavior of $\mathrm{Cu}$, etching rates and resulting surface morphologies. Finally, uniform IPs arrays with low reflectivity of $7.2 \%$ was prepared on silicon surface, and the etching rate was slow. Our work will contribute to a better understanding of the etching mechanism of $\mathrm{Cu}-\mathrm{ACE}$ and the formation process of inverted pyramid structure.

\section{Experiment process}

The diamond wire sawed (100)-oriented $\mathrm{n}$ type crystalline silicon wafers with thickness of 156 $\pm 5 \mu \mathrm{m}$ and resistivity of $1 \sim 3 \Omega \cdot \mathrm{cm}$ were used. Before the experiment, the wafers were cleaned in acetone, ethanol and deionized water for 10 mins under sonication, and then immersed in $10 \% \mathrm{HF}$ solution for 10 mins in order to remove native $\mathrm{SiO}_{2}$. Subsequently, the wafers were divided into three groups different mixture. First group (3 pieces) were placed in $\mathrm{HF} / \mathrm{H}_{2} \mathrm{O}_{2} / \mathrm{Cu}\left(\mathrm{NO}_{3}\right)_{2}$ (labeled $\mathrm{NO}_{3}{ }^{-}$system), $\mathrm{HF} / \mathrm{H}_{2} \mathrm{O}_{2} / \mathrm{CuSO}_{4}$ (labeled $\mathrm{SO}_{4}{ }^{2-}$ system) and $\mathrm{HF} / \mathrm{H}_{2} \mathrm{O}_{2} / \mathrm{CuCl}_{2}$ (labeled $\mathrm{Cl}^{-}$system) solution for 7 mins, so as to analyze the difference of etching morphology, etching rate and the resulting reflectivity. Second group (12 pieces) was placed in $\mathrm{HF} / \mathrm{Cu}\left(\mathrm{NO}_{3}\right)_{2}, \mathrm{HF} / \mathrm{CuSO}_{4}$ and $\mathrm{HF} / \mathrm{CuCl}_{2}$ deposition system for $5 \mathrm{~s}, 10 \mathrm{~s}, 30 \mathrm{~s}$ and $60 \mathrm{~s}$ in every system, so as to observe the evolution of copper deposition state on wafers in the absence of $\mathrm{H}_{2} \mathrm{O}_{2}$. Third group (12 pieces) was etched by the same three etching systems as the first group, and etching times were 1, 3, 5 and 7 mins in every system, in order to observe the morphology evolution of etching structures and deposited $\mathrm{Cu}$ nanoparticles $(\mathrm{Cu}-\mathrm{NPs})$. The detailed etching parameters were shown in tables 1 and 2. After etching, samples of group 1 were immersed into $\mathrm{HNO}_{3}$ solution to eliminate residual $\mathrm{Cu}$ NPs. Finally, the all samples were thoroughly rinsed with distilled water and dried in 
vacuum drying chamber. Moreover, the mass change of silicon wafer before and after etching were recorded to calculate the etching rate (Ra) based on Eq. (1), the relative amounts of deposited $\mathrm{Cu}$ (Q) were obtained by Eq. (2). The morphologies were characterized by scanning electron microscopy (SEM), the surface reflectivity of wafers was measured by the Ocean Optic USB-4100 spectrometer.

Table 1

Etching conditions of n-type monocrystalline silicon wafers by different copper salt system

Table 2

Deposition conditions of n-type monocrystalline silicon wafers by different copper salt system

$$
\begin{aligned}
& R_{a}=\frac{\Delta m}{2 \rho S t}(\mu \mathrm{m} / \mathrm{min}) \\
& \mathrm{Q}=\frac{\left(m_{3}-m_{2}\right) / m_{1}}{1000}
\end{aligned}
$$

Where $\Delta m$ is the mass loss of etched wafers $(\mathrm{g}), \rho$ is the mass density of crystalline silicon $\left(\mathrm{g} / \mathrm{cm}^{2}\right)$, $S$ is the silicon surface area $\left(\mathrm{cm}^{2}\right)$, and $t$ is the etching time ( $\left.\mathrm{min}\right), m_{1}$ is the mass of the as raw silicon wafer, $m_{2}$ is the mass of silicon wafer after deposition where the copper is cleaned by nitric acid, and $m_{3}$ is the mass of the wafer plus the deposited copper after deposition

\section{Results and discussion}

Fig. 1. (a) (c) SEM images of n-type silicon wafer under different copper salts system; (d) (f) the etching rate and reflectivity fitting diagram of the wafer under the three selected etching system.

Figures 1a, b, c show the top sectional SEM images of (100)-oriented crystalline silicon etched in $\mathrm{NO}_{3}{ }^{-}$system, $\mathrm{SO}_{4}{ }^{2-}$ system and $\mathrm{Cl}^{-}$system for $7 \mathrm{~min}$ at $40{ }^{\circ} \mathrm{C}$. As we can see, the etched silicon surface presents various morphologies when the anion species are different. The Cu-NPs exhibit anisotropic etching in $\mathrm{NO}_{3}{ }^{-}$and $\mathrm{SO}_{4}{ }^{2-}$ system, where uniform IPs with width of $0.8 \sim 1 \mu \mathrm{m}$ were formed under $\mathrm{NO}_{3}{ }^{-}$system, and variable IP-like structures were obtained under $\mathrm{SO}_{4}{ }^{2-}$ system. In addition, numerous oval pits with $5 \mu \mathrm{m}$ length and $1 \mu \mathrm{m}$ width were formed when wafers were etched in $\mathrm{Cl}^{-}$system, this structure is similar to that of $\mathrm{HF} / \mathrm{HNO}_{3}$ texturing method. In terms of reaction rate (see Fig. 1d), the etching rate of $\mathrm{NO}_{3}{ }^{-}$system is the lowest, followed by $\mathrm{Cl}^{-}$system, and etching rate of the $\mathrm{SO}_{4}{ }^{2-}$ system is the fastest. The IPs and IP-like structure owns low reflectance of $7.2 \%$ and $11.7 \%$, the oval pits obtained by $\mathrm{Cl}^{-}$system etching presents the highest reflectivity of 
$18.8 \%$ (see Figs. 1e, f), which may be due to the large size of the pit which is not conducive to the refraction of light. The results indicated that anions would greatly effect the etching behavior of $\mathrm{Cu}-$ NPs and leading to different morphologies and etching rate as well as reflectivity.

Fig. 2. SEM diagram of Cu-NPs morphology evolution of wafers treated in (a) (d) $\mathrm{HF} / \mathrm{Cu}\left(\mathrm{NO}_{3}\right)_{2}$ system, (e) $\sim \mathrm{h} \mathrm{HF} / \mathrm{CuSO}_{4}$ system and (i) (l) $\mathrm{HF} / \mathrm{CuCl}_{2}$ system for different time; (m) (o) Energy Dispersive Spectroscopy (EDS) spot scan results of the deposits in $\mathrm{HF} / \mathrm{Cu}\left(\mathrm{NO}_{3}\right)_{2}$ 、 $\mathrm{HF} / \mathrm{CuSO}_{4}$ and $\mathrm{HF} / \mathrm{CuCl}_{2}$ systems; (p) fitting diagram of copper deposition rate variation

Figures 2a-1 present the SEM imagines of silicon surface morphology processed in $\mathrm{HF} / \mathrm{Cu}\left(\mathrm{NO}_{3}\right)_{2}, \mathrm{HF} / \mathrm{CuSO}_{4}$ and $\mathrm{HF} / \mathrm{CuCl}_{2}$ system at different time duration. Figures $2 \mathrm{~m}, \mathrm{n}$, o show the EDS results of the deposited nano-particles when treated for $60 \mathrm{~s}$ in $\mathrm{NO}_{3}{ }^{-}, \mathrm{SO}_{4}{ }^{2-}$ and $\mathrm{Cl}^{-}$ deposition systems, respectively. It can be found that numerous Cu-NPs were deposited on silicon wafers surface in $\mathrm{HF} / \mathrm{Cu}\left(\mathrm{NO}_{3}\right)_{2}, \mathrm{HF} / \mathrm{CuSO}_{4}$ system. While for $\mathrm{Cl}^{-}$system, the $\mathrm{Cu}$ and $\mathrm{Cl}$ species was detected and their atomic ratio is nearly 1:1 (see Fig. 20), indicating $\mathrm{CuCl}$ precipitate forms on silicon wafer surface. Figures 2a, b, c, d show the morphology evolution of $\mathrm{Cu}-\mathrm{NPs}$ in $\mathrm{HF} / \mathrm{Cu}\left(\mathrm{NO}_{3}\right)_{2}$ system, at the first $10 \mathrm{~s}$ stage, a large number of $\mathrm{Cu}^{2+}$ ions capture electrons and deposit on the silicon surface, as the deposition time increases, $\mathrm{Cu}$-NPs gradually grow up and form bigger round copper particles. In the $\mathrm{HF} \mathrm{CuSO}_{4}$ system (see Figs. 2e, f, g, h), a dense copper film is formed and covered on the silicon surface at the beginning of deposition. Subsequently, some round copper particle appears when the deposition time reaches to $60 \mathrm{~s}$ like that of $\mathrm{HF} / \mathrm{Cu}\left(\mathrm{NO}_{3}\right)_{2}$ system. The current results indicate that $\mathrm{Cu}^{2+}$ ions can uniformly deposition with small size and form a dense copper film in the $\mathrm{HF} / \mathrm{CuSO}_{4}$ system. In $\mathrm{HF} / \mathrm{CuCl}_{2}$ system (see Figs. $2 \mathrm{i}, \mathrm{j}, \mathrm{k}, 1$ ), it is obvious that heavily agglomerated rod-shaped nano-particles appear along the saw marks regions. Figure $2 p$ shows the relative amount of the deposited Cu-NPs under three deposition systems, it can be seen that the amount of deposited $\mathrm{Cu}-\mathrm{NPs}$ in the $\mathrm{HF} / \mathrm{CuSO}_{4}$ system is slightly more than that in the $\mathrm{HF} / \mathrm{Cu}\left(\mathrm{NO}_{3}\right)_{2}$ system at the beginning stage of $30 \mathrm{~s}$, as the reaction proceeds, the amount of Cu-NPs deposited in $\mathrm{HF} / \mathrm{CuSO}_{4}$ system becomes much higher than that in $\mathrm{HF} / \mathrm{Cu}\left(\mathrm{NO}_{3}\right)_{2}$ system, by contrast, the amount of $\mathrm{Cu}-\mathrm{NPs}$ in $\mathrm{HF} / \mathrm{CuCl}_{2}$ system is the least.

Fig. 3. Diagram of deposition of $\mathrm{Cu}^{2+}$ in (a) $\mathrm{HF} / \mathrm{CuSO}_{4} \mathrm{system}$, (b) $\mathrm{HF} / \mathrm{Cu}\left(\mathrm{NO}_{3}\right)_{2}$ system, and (c) $\mathrm{HF} / \mathrm{CuCl}_{2}$ system

Figure 3 shows the schematic diagram of deposition process of $\mathrm{Cu}-\mathrm{NPs}$ in different systems. 
The deposition behavior of $\mathrm{Cu}$ is related to anion concentration and anion properties [24-28]. Although the concentration of $\mathrm{Cu}^{2+}$ is the same in the three deposition systems, the anion concentration is different. Compared with $\mathrm{NO}_{3}{ }^{-}$and $\mathrm{Cl}^{-}$, the concentration of $\mathrm{SO}_{4}{ }^{2-}$ is the lowest, which leads to the weakest electrostatic attraction between $\mathrm{SO}_{4}{ }^{2-}$ and $\mathrm{Cu}^{2+}$, thus the $\mathrm{Cu}^{2+}$ ions are easier to get electrons and evenly deposit on silicon surface as shown in Fig. 3a. Moreover, the difference in the surface energy of the silicon wafer has no great influence on the $\mathrm{Cu}$ deposition in $\mathrm{HF} / \mathrm{CuSO}_{4}$ system, which leads to the $\mathrm{Cu}-\mathrm{NPs}$ is dispersed and form a dense film. $\mathrm{In} \mathrm{HF} / \mathrm{Cu}\left(\mathrm{NO}_{3}\right)_{2}$ system, the higher concentration of anion concentration enhances the attraction between $\mathrm{NO}_{3}{ }^{-}$and $\mathrm{Cu}^{2+}$ and thus limits the copper ions deposition (see Fig. 3b), which causes the Cu-NPs tend to deposit at the saw marks and defect sites, slightly agglomerated and grow into bigger round particle. With the reaction proceeds, the $\mathrm{NO}_{3}{ }^{-}$also oxidize $\mathrm{Cu}-\mathrm{NPs}$ into $\mathrm{Cu}^{2+}$ ions, which controls the size of the copper particles not to be too large, and the deposition rate is slower.

As for $\mathrm{HF} / \mathrm{CuCl}_{2}$ system, the concentration of $\mathrm{Cl}^{-}$is the same as that of $\mathrm{NO}_{3}{ }^{-}$in $\mathrm{HF} / \mathrm{CuCl}_{2}$ system. But due to the more stable covalent bond of $\mathrm{CuCl}_{2}$, the $\mathrm{Cu}^{2+}$ tends to be more difficult to break free and deposition. Moreover, many $\mathrm{Cu}^{2+}$ and the deposited $\mathrm{Cu}-\mathrm{NPs}$ are prone to form $\left[\mathrm{CuCl}_{2}\right]^{-}$complexes in rich $\mathrm{Cl}^{-}$solution, and further form $\mathrm{CuCl}$ precipitate[29], as shown in Fig. 3c, the specific reaction equations are shown in Eqs. (3)-(6) [29,30].

$$
\begin{aligned}
\mathrm{Cu}^{2+}+2 \mathrm{e}^{-} & \rightarrow \mathrm{Cu} \\
\mathrm{Cu}^{2+}+2 \mathrm{Cl}^{-}+\mathrm{e}^{-} & \rightarrow\left[\mathrm{CuCl}_{2}\right]^{-} \\
\mathrm{Cu}^{2+}+2 \mathrm{Cu}+4 \mathrm{Cl}^{-} & \rightarrow 2\left[\mathrm{CuCl}_{2}\right]^{-} \\
{\left[\mathrm{CuCl}_{2}\right]^{-} } & \rightarrow \mathrm{CuCl} \downarrow+\mathrm{Cl}^{-}
\end{aligned}
$$

Besides, due to the large number of $\left[\mathrm{CuCl}_{2}\right]^{-}$complexes, the migration of ions in the solution is greatly hindered, these factors make the $\mathrm{Cu}^{2+}$ really difficult to get electronic and deposit on silicon surface, so that the $\mathrm{Cu}$ particles and $\mathrm{CuCl}$ precipitate preferentially deposit along the saw marks and defect sites and heavily agglomerated into a rod-shaped structure. It can be seen that the chemical properties of anions greatly affect the deposition of $\mathrm{Cu}-\mathrm{NPs}$, which affects the etching behavior during the $\mathrm{Cu}-\mathrm{ACE}$.

Fig. 4. SEM images of nano-structures evolution of wafers etched in (a) (d) $\mathrm{NO}_{3}{ }^{-}$system, (e) (h) $\mathrm{SO}_{4}{ }^{2-}$ system and (i) (l) $\mathrm{Cl}^{-}$system for different time 
Figure 4 presents the evolution process of IPs, IP-like and oval pit structure when silicon wafer was etched in $\mathrm{NO}_{3}{ }^{-}, \mathrm{SO}_{4}{ }^{2-}$ and $\mathrm{Cl}^{-}$system for 1 min, 3 mins, 5 mins, 7 mins. For the $\mathrm{NO}_{3}{ }^{-}$system (see Figs. 4a, b, c, d). As we can see, irregular pits are formed along the saw marks at the beginning stage, then, a small amount of IPs are scattered on the silicon surface, when it's up to 5 mins, IPs get bigger and closely gather on the surface with wide of about $800 \sim 1000 \mathrm{~nm}$, moreover, the saw marks are also removed, until 7 mins, the inverted pyramids merged with each other and the IPs structure are destroyed, which is caused by excessive etching. For the $\mathrm{SO}_{4}{ }^{2-}$ system (see Figs. 4e, f, $\mathrm{g}, \mathrm{h}$ ), numerous pits with different sizes appear along the saw marks at the first 3 mins, when it's up to 5 mins, the pits grows into big grooves and some IP-like structures are formed, as reaction goes on, more IP-like structures with various size can be seen, which indicates that the anisotropic etching ability of copper in $\mathrm{SO}_{4}{ }^{2-}$ system is not obvious as that in $\mathrm{NO}_{3}{ }^{-}$system. As for $\mathrm{Cl}^{-}$system (see Figs. $4 \mathrm{i}, \mathrm{j}, \mathrm{k}, \mathrm{l})$, crescent-shaped grooves appear at the beginning of the reaction, and the crescent-shaped pits gradually widening and deepening, eventually change into elliptical pits with various lengths, as seen in Fig. 41.

Fig. 5. SEM images of Cu-NPs morphology evolution of wafers etched in (a) (d) $\mathrm{NO}_{3}^{-}$ system, (e) (h) $\mathrm{SO}_{4}{ }^{2-}$ system and (i) (l) $\mathrm{Cl}^{-}$system for different time

\section{Fig. 6. Diagram of average etching rate at different etching times for different system}

To further explore the difference of copper etching behavior in different copper salt systems, the morphology revolution of $\mathrm{Cu}-\mathrm{NPS}_{\mathrm{s}}$ in $\mathrm{NO}_{3}{ }^{-}, \mathrm{SO}_{4}{ }^{2-}$ and $\mathrm{Cl}^{-}$system at different etching time was studied, the SEM pictures are show in Fig. 5. For $\mathrm{NO}_{3}{ }^{-}$system (see Figs. 5a, b, c, d), large amount of rounded and scattered Cu-NPs was deposited on the surface at the beginning, with the extension of reaction time, some $\mathrm{Cu}-\mathrm{NPs}$ were oxidized to $\mathrm{Cu}^{2+}$ by $\mathrm{H}_{2} \mathrm{O}_{2}$, so the number of $\mathrm{Cu}-\mathrm{NPs}$ is decreased,. When etching time is 7 mins, $\mathrm{Cu}-\mathrm{NPs}$ are invisible but some small pits appear at the bottom of the round deep pits where Cu-NPs have been deposited. Figures 5e, f, g, h show the situation of $\mathrm{Cu}-\mathrm{NPs}$ in $\mathrm{SO}_{4}{ }^{2-}$ system, it can be seen that at the beginning of the reaction, lots of $\mathrm{Cu}$ NPs are deposited on the sidewalls of the pits which is similar to the situation of $\mathrm{NO}_{3}{ }^{-}$system, but the size of $\mathrm{Cu}-\mathrm{NPs}$ is smaller. As the reaction proceeds, the $\mathrm{Cu}$ particles become less and smaller. The small pits on the sidewall (see Fig. $5 \mathrm{~g}$ ) can infer that the copper-assisted chemical etching intensely happens. As for $\mathrm{Cl}^{-}$system (see Figs. 5i, j, k, l), a large amount of $\mathrm{Cu}$ and $\mathrm{CuCl}$ particles 
were stacked in the crescent-shaped groove at $1 \mathrm{~min}$, and the size is much bigger than that in $\mathrm{NO}_{3}{ }^{-}$ and $\mathrm{SO}_{4}{ }^{2-}$ system. These deposits $(\mathrm{CuCl}$ particles) becomes bigger as the reaction goes on, in which is contrary to the situation of $\mathrm{NO}_{3}{ }^{-}$and $\mathrm{SO}_{4}{ }^{2-}$ system.

Different copper etching behaviors naturally lead to different etching rates (see Fig. 6). it is obvious that at the beginning of reaction, the etching rate of $\mathrm{SO}_{4}{ }^{2-}$ system is much higher than the others, and rapidly decreased to $1.52 \mu \mathrm{m} / \mathrm{min}$. While the etching rate of $\mathrm{NO}_{3}{ }^{-}$system and $\mathrm{Cl}^{-}$system are very close and both stable at about $1 \mu \mathrm{m} / \mathrm{min}$.

Fig. 7. Diagram of etching behavior of $\mathrm{Cu} / \mathrm{CuCl}$ in (a) $\mathrm{SO}_{4}{ }^{2-}$ system, (b) $\mathrm{NO}_{3}^{-}$system and (c) $\mathrm{Cl}^{-}$system

Figure. 7 elaborates the role of $\mathrm{Cu}$ to form different structure in the above three copper salt systems,. Due to the weak electrostatic attraction, Cu evenly deposited on the silicon surface. These tiny $\mathrm{Cu}-\mathrm{NPs}$ with high surface activity, lead to intense reaction, but they are quickly oxidized by $\mathrm{H}_{2} \mathrm{O}_{2}$ (see Fig. 7a), therefore, only a large number of corrosion pits and a few small Cu-NPs lied on the side wall as the reaction goes on, and the corresponding reaction rate rapidly decrease, even so the average etching rate at 7 mins is still much higher than the other two. Due to the intense reaction, the anisotropic etching ability of $\mathrm{Cu}-\mathrm{NPs}$ cannot be completely demonstrated, so the regular IP structures cannot be formed but many IP-like structures instead. In $\mathrm{NO}_{3}{ }^{-}$system, $\mathrm{H}_{2} \mathrm{O}_{2}$ and $\mathrm{NO}_{3}{ }^{-}$ make the $\mathrm{Cu}-\mathrm{NPs}$ the proper size, which can fully demonstrate an anisotropic etching ability, and eventually form a regular IP structure as shown in Fig. 7b. Moreover, the proper size of Cu-NPs make the reaction mild and the reaction rate is always keep about $1 \mu \mathrm{m} / \mathrm{min}$. For the $\mathrm{Cl}^{-}$system (see Fig. 7c), Cu-NPs and CuCl-NPs will both deposit on the silicon surface, the $\mathrm{H}_{2} \mathrm{O}_{2}$ can oxidize $\mathrm{Cu}$ NPs, but it has no effect on the CuCl-NPs. Therefore, as the reaction proceeds, a large amount of $\left[\mathrm{CuCl}_{2}\right]^{-}$complex ions changed into $\mathrm{CuCl}$ precipitate and agglomerate in the corrosion pits. Moreover, due to the uneven deposition, the resulting structure is not uniform, leading to numerous oval pits with different size, and the cutting lines are still obvious after etching, the slow etching rate of $\mathrm{Cl}^{-}$system is mainly due to the slow deposition rate of $\mathrm{Cu}^{2+}$.

\section{Conclusion}

The effects of $\mathrm{NO}_{3}^{-}, \mathrm{SO}_{4}{ }^{2-}$ and $\mathrm{Cl}^{-}$on the etching morphology of n-type single crystal silicon in the copper-assisted etching process are firstly systematically analyzed, the different anions affects 
the copper deposition process, result in different etching rates and behaviors.

The weak attraction between $\mathrm{SO}_{4}{ }^{2-}$ species and $\mathrm{Cu}^{2+}$ ions leads to that $\mathrm{Cu}^{2+}$ deposition is quick and easily form tiny $\mathrm{Cu}-\mathrm{NPs}$, which causes intense reaction process and result in lots of grooves and inverted pyramid-like structure. In the $\mathrm{Cl}^{-}$species etching system, the covalent bond of $\mathrm{CuCl}_{2}$ and formation of $\left[\mathrm{CuCl}_{2}\right]^{-}$complex ions lead to that the $\mathrm{Cu}^{2+}$ ions preferentially deposit in defects sites and agglomerate into rod-shaped particles, resulting in oval corrosion pits, which is not conductive to saw marks' removal.

In comparison, the $\mathrm{NO}_{3}{ }^{-}$species show stronger oxidation and which can relieve the $\mathrm{Cu}-\mathrm{NPs}$ aggregation, these $\mathrm{Cu}-\mathrm{NPs}$ with proper size show better anisotropic etching ability, thus forming regular inverted pyramid structure which can almost completely disappeared saw marks and lower reflection to $7.2 \%$. It can be seen that the type of anion does affect the etching behavior of $\mathrm{Cu}-\mathrm{NP}$ to form different morphologies, through this work we can further understands the formation mechanism of inverted pyramid by $\mathrm{HF} / \mathrm{H}_{2} \mathrm{O}_{2} / \mathrm{Cu}\left(\mathrm{NO}_{3}\right)_{2}$ system, moreover, it provides guidance for controllable preparation of inverted pyramid structure and future high efficiency single crystal solar cells.

\section{Acknowledgments}

Financial support of this work from the National Natural Science Foundation of China (Grant No. 51974143, 51904134, 61764009, 51762043); National Key R\&D Program of China (No. 2018YFC1901801, No. 2018YFC1901805); Major Science and Technology Projects in Yunnan Province (No. 2019ZE007); Key Project of Yunnan Province Natural Science Fund (No. 2018FA027); Yunnan Ten Thousand Talents Project (YNWR-QNBJ-2018-111) and the Program for Innovative Research Team in University of Ministry of Education of China (No. IRT_17R48).

\section{Compliance with Ethical Standards:}

\section{Conflicts of interest}

The authors declare that they have no known competing financial interests or personal relationships that could have appeared to influence the work reported in this paper.

\section{Ethics approval}

The authors declare that the manuscript is not currently being considered for publication in another journal

\section{Consent to participate}


I testify on behalf of all co-authors that our article submitted to Silicon.

\section{Consent for Publication}

On behalf of all the authors, I agree that our article should be published in Silicon

\section{Availability of data and material}

The authors declare this data and material has not been published in whole or in part elsewhere.

\section{Code availability}

Not applicable

\section{Authors' contributions}

All authors have been personally and actively involved in substantive work leading to the manuscript, and will hold themselves jointly and individually responsible for its content.

\section{References}

1. Agency IRE (2020) Global Renewables Outlook: Energy transformation 2050. https://www.irena.org/publications/2020/Apr/Global-Renewables-Outlook-2020.

2. Teske S, Sawyer S, Schäfer O, Pregger T, Simon S, Naegler T (2015) energy revolution-A $\begin{array}{llll}\text { SUSTAINABLE } & \text { WORLD } & \text { OUTLOOK } & \end{array}$ https://www.duesseldorf.greenpeace.de/sites/www.duesseldorf.greenpeace.de/files/greenpeace energyrevolution_erneuerbare_2050_20150921.pdf.

3. Jäger-Waldau A (2020) Snapshot of Photovoltaics-February 2020. Energies 13 (4):1-8

4. Chen J, Zhao S, Gao T, Yuzeng XU, Zhang L, Ding Y, Zhang X, Zhao Y, Hou G (2019) High-efficiency Monocrystalline Silicon Solar Cells:Development Trends and Prospects. Materials Reports 5. Zhang S, Yao Y, Hu D, Lian W, Qian H, Jie J, Wei Q, Ni Z, Zhang X, Xie L (2019) Application of Silicon Oxide on High Efficiency Monocrystalline Silicon PERC Solar Cells. Energies 12 (6)

6. Gao J, Song Z, Guo Y, Qu X, Zhang T (2019) Field Passivation of the Front Surface of n-Type Heterojunction and Back Contact Solar Cells. Micronanoelectronic Technology

7. Kivambe M, Haschke J, Horzel J, Assa B, Tabet N (2019) Record Efficiency N-type and Highefficiency P-type Mono-like Silicon Heterojunction Solar Cells with High Temperature Gettering Process. ACS Appl Energy Mater

8. Shetty K, Kaushal Y, Chikkan N, Murthy D, Kumar CM (2020) Challenges in Processing Diamond Wire Cut and Black Silicon Wafers in Large-Scale Manufacturing of High Efficiency Solar Cells. J Power Energy Eng 8 (2):65-77

9. Kanti BP, Sreejith KP, Yadav TS, Anil K, Kumar SA (2018) Novel low-cost alkaline texturing process for diamond-wire-sawn industrial monocrystalline silicon wafers. Sol Energy Mater Sol Cells 185:406414

10. Kumagai A (2015) Texturization using metal catalyst wet chemical etching for multicrystalline diamond wire sawn wafer. Sol Energy Mater Sol Cells 133:216-222

11. Huang Z, Geyer N, Werner P, Boor JD, Goesele U (2011) Metal-assisted chemical etching of silicon: a review. Adv Mater 23 (2):285-308

12. Chen W, Liu Y, Wu J, Chen Q, Zhao Y, Wang Y, Du X (2019) High-Efficient Solar Cells Textured by 
$\mathrm{Cu} / \mathrm{Ag}$-Cocatalyzed Chemical Etching on Diamond Wire Sawing Multicrystalline Silicon. ACS Appl Mater Interfaces 11: 10052-10058

13. He X, Li S, Ma W, Ding Z, Yu J, Qin B, Yang J, Zou Y, Qiu J (2017) A simple and low-cost chemical etching method for controllable fabrication of large-scale kinked silicon nanowires. Mater Lett 196:269272

14. He X, Zou Y, Sheng G, Feng Q, Qiu J, He Y, Li S, Ma W (2017) Research on controllable preparation and antireflection properties of zigzag SiNWs arrays. Integr Ferroelectr 182:65-74

15. Zou Y, Li S, Ma W, Ding Z, Xi F, Lei Y, Chen Z (2017) Research on surface nano-texturation and wet-chemical passivation of multi-crystalline silicon wafer. J Mater Sci: Mater Electron 28 (24):1-10

16. Yang L, Liu Y, Wang Y, Chen W, Chen Q, Wu J, Kuznetsov A, Du X (2017) 18.87\%-efficient inverted pyramid structured silicon solar cell by one-step $\mathrm{Cu}$-assisted texturization technique. Sol Energy Mater Sol Cells 166:121-126

17. Wang Y, Liu Y, Yang L, Chen W, Du X, Kuznetsov A (2017) Micro-structured inverted pyramid texturization of Si inspired by self-assembled Cu nanoparticles. Nanoscale 9 (2):907-914

18. Chen Q, Liu Y, Wang Y, Chen W, Wu J, Zhao Y, Du X ( 2019) Optical properties of a random inverted pyramid textured silicon surface studied by the ray tracing method. Sol Energy 186:392-397

19. Chen W, Liu Y, Yang L, Wu J, Chen Q, Zhao Y, Wang Y, Du X (2018) Difference in anisotropic etching characteristics of alkaline and copper based acid solutions for single-crystalline Si. Sci Rep-UK $8: 10843$

20. Huang Z, Gao K, Wang X, Xu C, Song X, Shi L, Zhang Y, Hoex B, Shen W (2019) Large-area MACE Si nano-inverted-pyramids for PERC solar cell application. Sol Energy 188:300-304

21. Zhao J, Wang A, Green M (2001) High-efficiency PERL and PERT silicon solar cells on FZ and MCZ substrates. Sol Energy Mater Sol Cells 65 (1-4):429-435

22. Wang Y, Yang L, Liu Y, Mei Z, Chen W, Li J, Liang H, Kuznetsov A, Xiaolong D (2015) Maskless inverted pyramid texturization of silicon. Sci Rep-UK 5:10843

23. Wu J, Liu Y, Chen Q, Chen W, Yang L, Wang Y, He M, Du X (2018) The orientation and optical properties of inverted-pyramid-like structures on multi-crystalline silicon textured by $\mathrm{Cu}$-assisted chemical etching. Sol Energy 171:675-680

24. Sheng G, Zou Y, Li S, Ma W, Ding Z, Xi F, Geng C, He Z, Chen Z, Yang J (2018) Controllable nanotexturing of diamond wire sawing polysilicon wafers through low-cost copper catalyzed chemical etching. Mater Lett 221:85-88

25. Rao TS, Page AL, Coleman NT (1968) The Influence of Ionic Strength and Ion-Pair Formation Between Alkaline-Earth Metals and Sulfate on Na-Divalent Cation-Exchange Equilibria1. Soil Sci Soc Am J 32 (5):639-643

26. Yu TR, Beyme B, Richter J (2010) Direct determination of potassium-calcium activity ratio in soils with two ion-selective electrodes. II. Interactions of potassium and calcium ions with soils. J Plant Nutr Soil Sci 152 (4):359-365

27. Karayannis $\mathrm{H}$, Patermarakis $\mathrm{G}$ Effect of the $\mathrm{Cl}^{-}$and $\mathrm{SO}_{4}{ }^{2-}$ ions on the selective orientation and structure of Ni electrodeposits. In: International Diatom Symposium, 1995.

28. Hardesty, David, W. (1970) Anion Effects in Copper Deposition. Journal of the Electrochemical Society

29. Turaev DY, Kruglikov SS, Parfenova AV (2005) Regeneration by Membrane Electrolysis of an Etching Solution Based on Copper Chloride. Russ J Appl Chem 78 (9):1444-1449

30. Otmai H, Telegdi J, Papp K, Stupniek-Lisac E (2004) Protective Properties of An Inhibitor Layer 
Formed on Copper in Neutral Chloride Solution. J Appl Electrochem 34 (5):545-550 


\section{Figures}
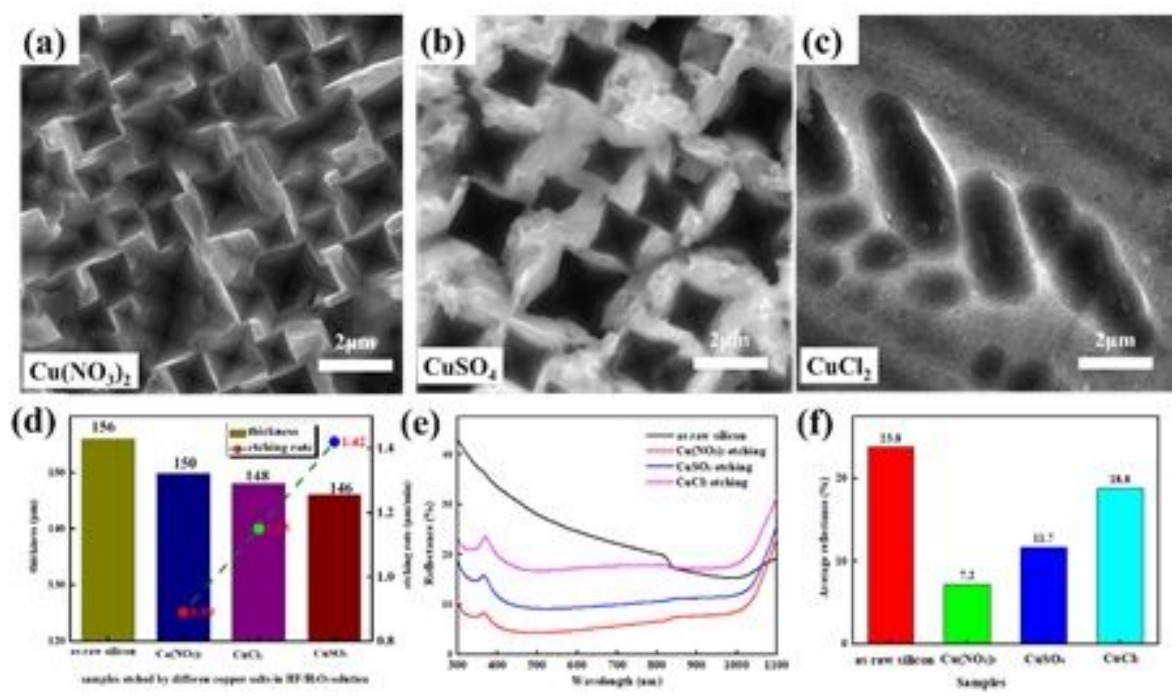

Figure 1

(a) (c) SEM images of n-type silicon wafer under different copper salts system; (d) (f) the etching rate and reflectivity fitting diagram of the wafer under the three selected etching system.
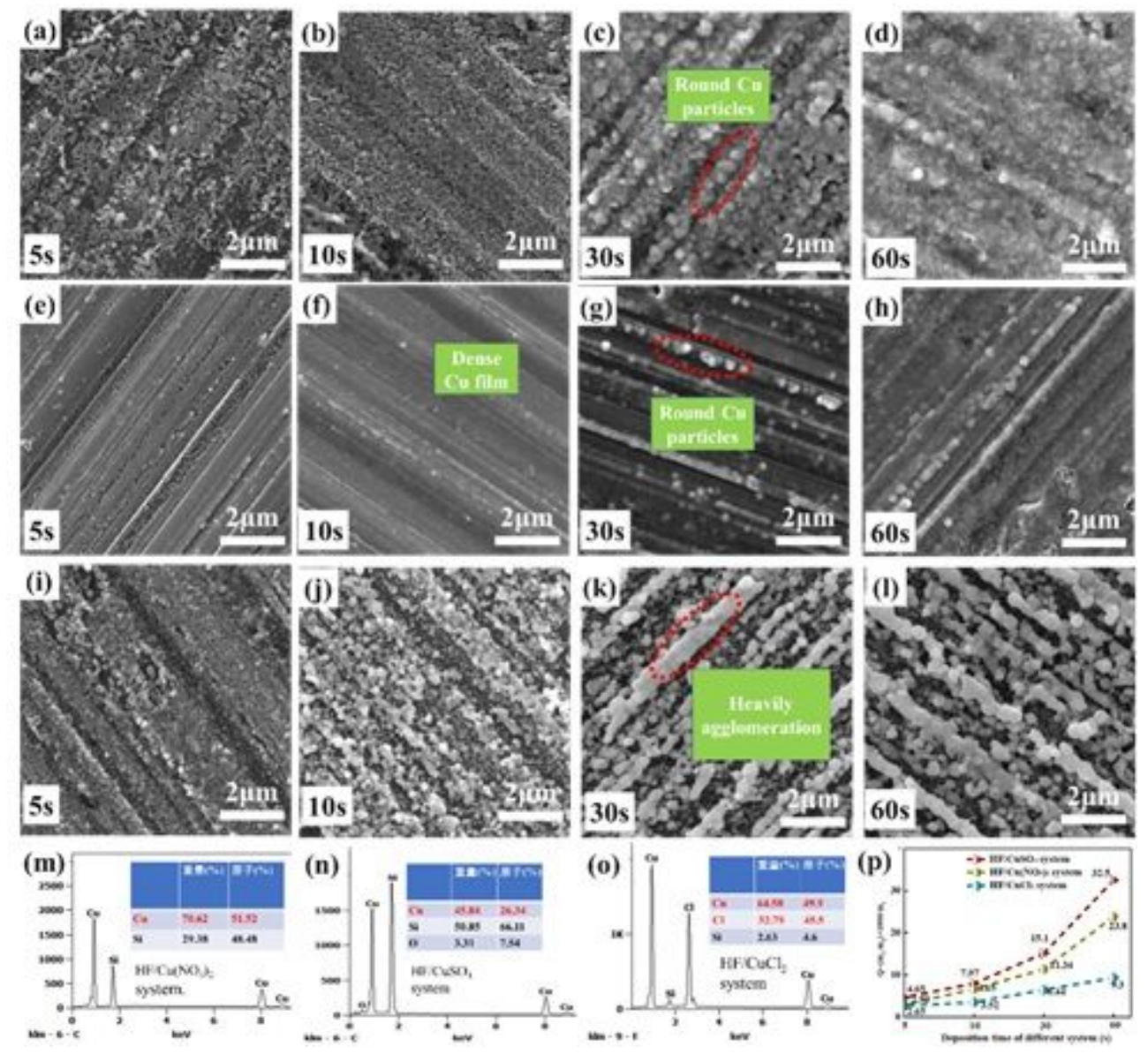

Figure 2 
SEM diagram of Cu-NPs morphology evolution of wafers treated in (a) (d) HF/Cu(NO3)2 system, (e) (h) $\mathrm{HF} /$ CuSO4 system and (i) (l) HF/CuCl2 system for different time; (m) (o) Energy Dispersive Spectroscopy (EDS) spot scan results of the deposits in $\mathrm{HF} / \mathrm{Cu}(\mathrm{NO} 3) 2 \square \mathrm{HF} / \mathrm{CuSO} 4$ and $\mathrm{HF} / \mathrm{CuCl} 2$ systems; $(p)$ fitting diagram of copper deposition rate variation.

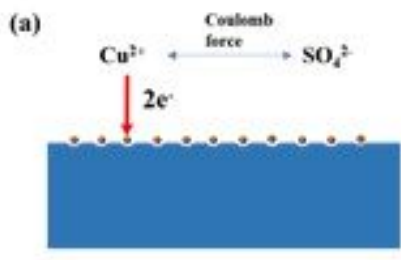

Round Cu-NPs

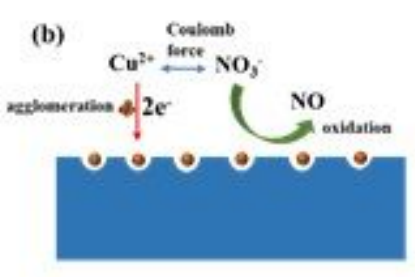

- Rod shaped Cu-NPs

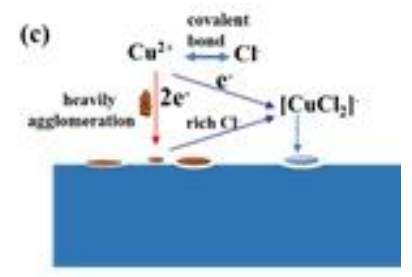

- Red shaped precipitate

\section{Figure 3}

Diagram of deposition of Cu2+ in (a) HF/CuSO4 system, (b) $\mathrm{HF} / \mathrm{Cu}(\mathrm{NO} 3) 2$ system, and (c) $\mathrm{HF} / \mathrm{CuCl} 2$ system.
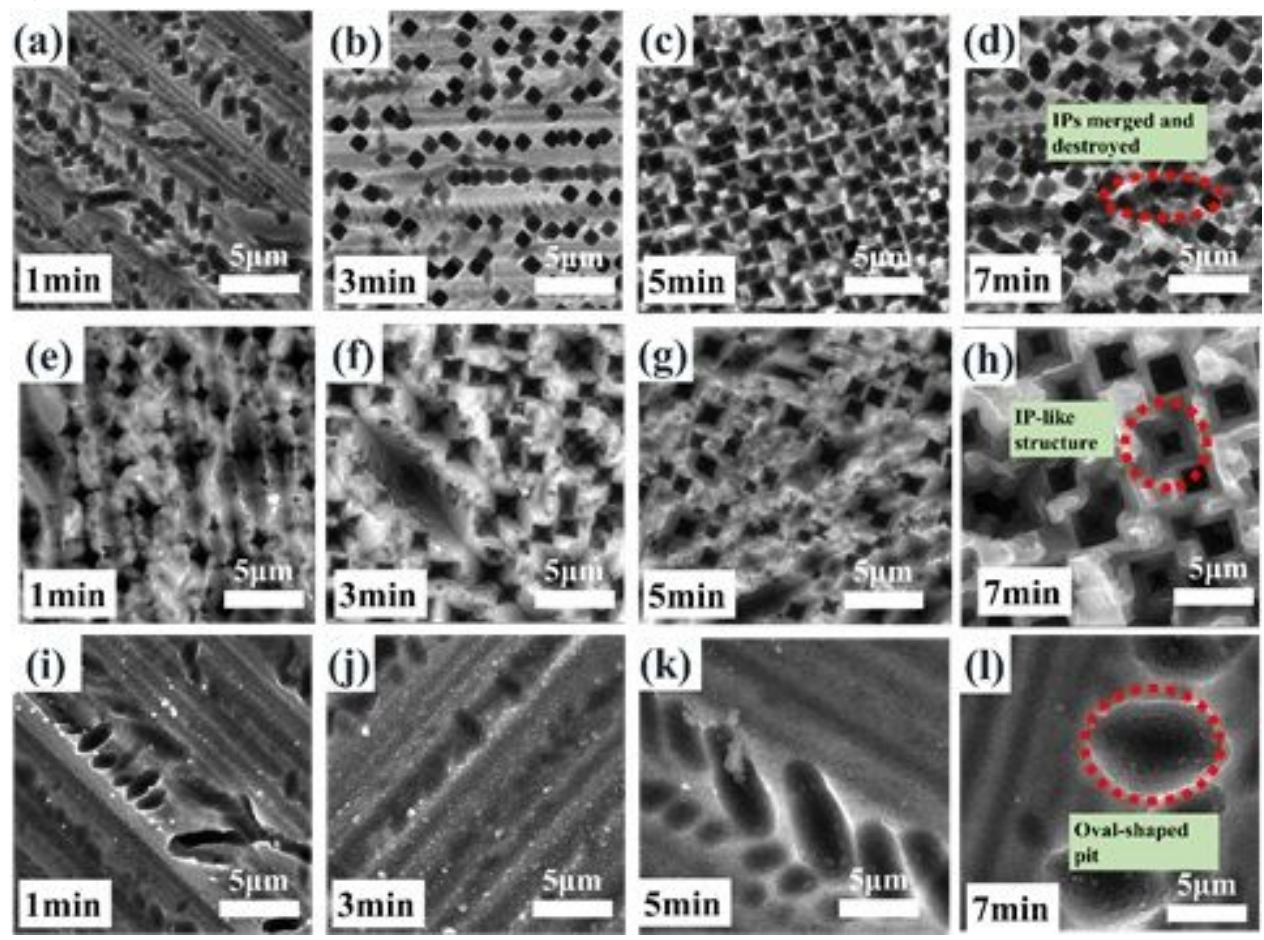

Figure 4

SEM images of nano-structures evolution of wafers etched in (a) (d) NO3- system, (e) (h) SO42- system and (i) (I) Cl-system for different time 

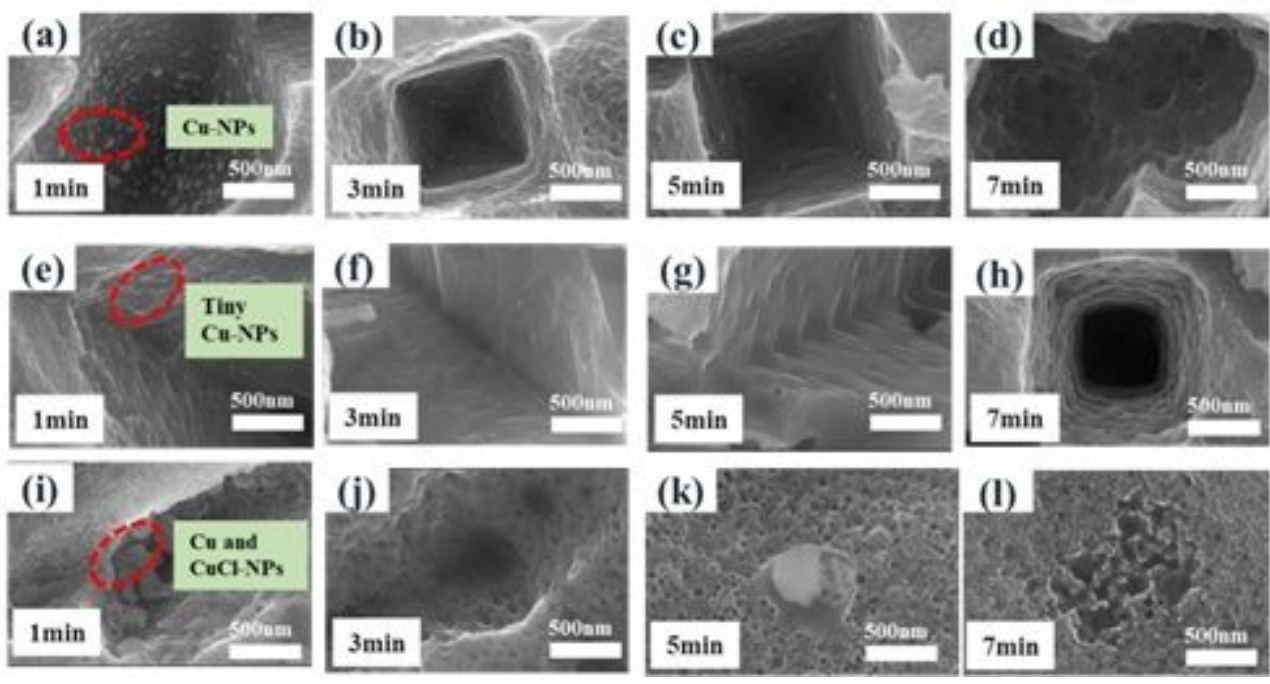

Figure 5

SEM images of Cu-NPs morphology evolution of wafers etched in (a) (d) NO3- system, (e) (h) SO42system and (i) (I) Cl- system for different time.

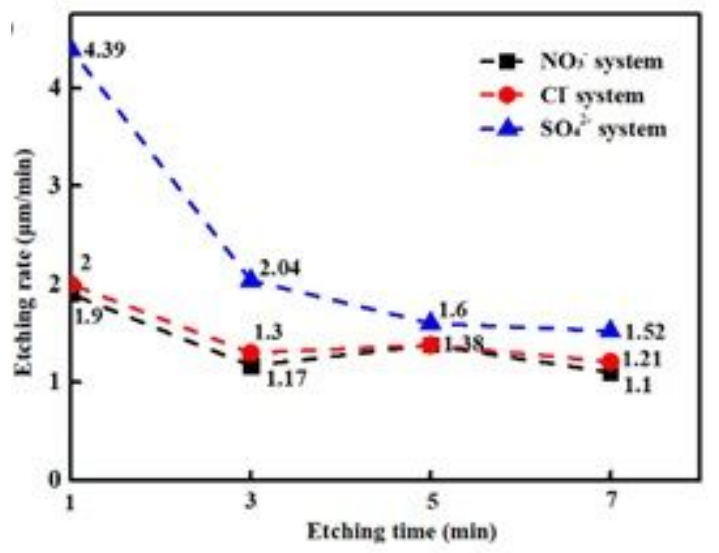

\section{Figure 6}

Diagram of average etching rate at different etching times for different system

(a)
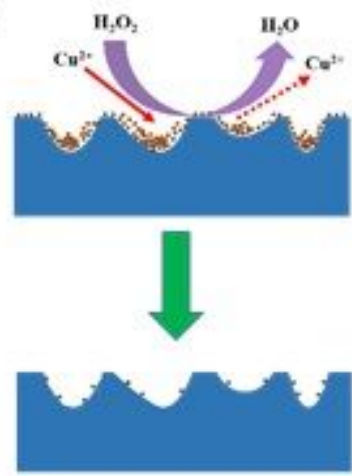

Cu-NPs (b)

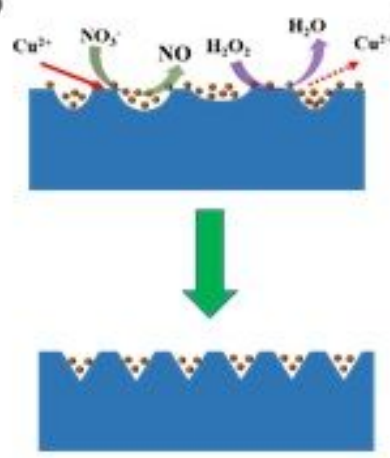

)
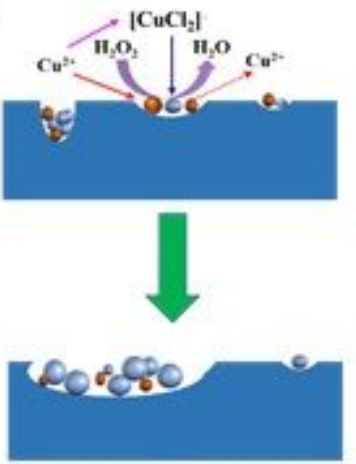

CuClprecipitate

Figure 7 
Diagram of etching behavior of $\mathrm{Cu} / \mathrm{CuCl}$ in (a) SO42- system, (b) NO3- system and (c) Cl- system 